\title{
INFLUENCE OF EMPLOYEES EVALUATION ON ORGANISATIONAL LEARNING AT LEISURE \& SPORTS CLUBS
}

\section{Edmundas Jasinskas, Dalia Štreimikienè, Biruta Švagždienè, Artūras Simanavičius}

\section{Introduction}

Solid opinion is noticed [10], [11], [15], [37], [43], that evaluation of individual and organisational learning is in particular complicated process. Aksu \& Özdemir [2], Jaseviciute - Ufartiene, Mejeryte - Narkeviciene \& Widelska [14], Örtenblad [29], Phillips [30], Stewart [39], accentuate the essence of learning organisation and claim that implementation of the model of learning organisation in practice is very difficult. Works of mentioned scientists are mostly focused on transformation of traditional organisation into learning organisation.

Scientific problem - in order to maintain competitive ability the organisation must constantly learn and accumulate knowledge. Organisational learning though is not identical to individual however it is closely related with individual learning. Usually the employee behaves in the way he is evaluated for, therefore one of important conditions for constant organisational and separate employee learning is suitable evaluation of employees. Usually large organisations have better opportunities to hire specialists of human resources' management, while it is much more difficult to properly and objectively evaluate employees in small organisations, such as leisure \& sports clubs. The aim of research is to determine what employees' evaluation methods at leisure \& sports clubs of Alytus city more influence the becoming of organisation as learning organisation.

Aim of article - to determine the influence of employees' evaluation on organisational learning at leisure \& sports clubs of Alytus city.

Research object - influence of employees' evaluation on organisation learning at leisure \& sports clubs of Alytus city.

Methods used. Analysis of scientific literature (in order to systematise the approach of representatives of theory of learning organisation to influence of employees' evaluation on the learning); questionnaire (managers and specialists of sports clubs of Alytus city), descriptive statistics analysis (systematising data of questionnaire).

\section{Influence of Employees' Evaluation on Organisational Learning: Theoretic Aspect}

In scientific literature [3], [40] the main employees' evaluation methods are emphasized dividing them into individual (360 degrees of feedback, individual evaluation, free (not structured), descriptive (qualitative), combined (interim), quantitative and team (of comparative evaluation, structured, special). Advantages of individual methods were accentuated: definite number of assessors, employees are evaluated each individually, strict complex of criteria is determined, however free characteristic forms also exist, determination of employees' features and works prevail; disadvantages: evaluation takes much time, data obtained may not be compared, employees are divided into "very good“, "good“ and „bad“, methods are oriented towards several goals. Advantages of team methods: strong and weak sides of employees are accentuated, methods are oriented towards special goals (organisational learning aspect may also be included), entire group of employees is evaluated at the same time; disadvantages: employees are divided into "the best“ and "the worst". However according to the features of employees' evaluation methods the scientists do not accentuate their effect to organisational learning, though the behaviour in one way or another is influenced by evaluation, therefore the influence on learning when applying different methods may also be different.

The main goal of employees' activity evaluation is to increase interest of all employees in success of activity and to create 
additional assumptions for the increase of their efficiency [5].

Efficient learning is particularly related to evaluation of employees' activity in organisation. Darškuvienè et al. [7] claim, that in learning process in order to increase its efficiency as well as to ensure closer learning relationship with practical managerial activity, the problems of managerial competence determination and assessment are very urgent.

Phillips [30], Simonaitienè [38] present different learning characteristics, mostly supplemented and accentuated by Senge [36] with five disciplines necessary to learning organisation. The authors have also gone deeper to the following aspects: climate and culture as the environment motivating learning [2], process of learning [2], [18], [39], where learning of one or too loops is accentuated, and Stewart [39] presents new learning level, i.e., learning of three loops. Besides, individual and organisational learning were analysed [4], [2], [30], [39]. Also the structure of learning organisation was analysed [32], [38], as well as its advantages, benefit coming out through teaching-learning results [6], [17]. Appropriate organisation structure, as Yasin \& Zimmerer [13] prove, motivates to enhance service quality.

Aivaz \& Vancea [1], Hopeniene et al. [12], Koneenik \& Ruzzier [23], Malakauskaite \&
Navickas [25], Savrina et al. [35] notice that sector of tourism and leisure \& sports is growing up. For further development of tourism and leisure \& sports services a good knowledge management and well prepared management specialists are necessary [19], [20], [21], [42].

Knowledge acquired by employees directly influences competitive ability as well as provided service quality [16], [24], [26], [27], [28], [33], [34].

People are the main characters in knowledge society. The most valuable feature is the ability of human in continuously changing environment to use knowledge effectively and reasonably. Continual education and learning is the best way to accept challenges of changes.

After review of the studies made in the sphere of learning and employees' evaluation, it may be stated that nowadays it is very important to carry out employees' evaluation in organisation and to determine its relationship with learning. For that purpose, referring to scientific literature analysis, we have created theoretical model of employees' evaluation influence on organisational learning (see Figure 1). It is assumed in the model that team methods of employees' evaluation at leisure \& sports clubs more affect the characteristics of learning organisation features than individual methods of employees' evaluation.

\section{Fig. 1: Theoretical model of employees' evaluation influence on organisational learning}

\begin{tabular}{|c|c|c|}
\hline \multicolumn{2}{|c|}{$\begin{array}{l}\text { ACTIVITY EVALUATION } \\
\text { METHODS }\end{array}$} & LEARNING ORGANISATION FEATURES \\
\hline \multirow{6}{*}{ 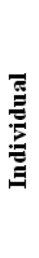 } & 360 degrees offeedback & Environment, climate suitable for training \\
\hline & Individual evaluation & Communication and cooperation of organisation members \\
\hline & Free (not structured) & Response to public and environmental needs \\
\hline & Descriptive (qualitative) & $\begin{array}{l}\text { Learning, education, knowledge accumulation of organisation } \\
\text { members oriented towards pursue of particular goals }\end{array}$ \\
\hline & Combined (interim) & Formation of vision, mission, strategy, organised as training \\
\hline & Quantitative & process \\
\hline \multirow{4}{*}{$\underset{\mathscr{E}}{\stackrel{\Xi}{E}}$} & Connarative euvaluation & Open organisation expanding its efficiency range \\
\hline & & Continuously learning organization \\
\hline & Structured & 3 loop training \\
\hline & Special & $\begin{array}{c}\text { Processes of efficient knowledge exchange applying up-to-date } \\
\text { technologies of information transfer }\end{array}$ \\
\hline
\end{tabular}


In presented model we may see individual and team methods of employees' evaluation (accentuated according to Bakanauskienè et al. [5]; Gimžauskienè [9]; Kumpikaitè [22]; Pundzienè [31]; Tubutienè \& Morkūnaitè [41]; Zuzevičiūtè \& Teresevičius [44]) and learning organisation features (made referring to Aksu \& Özdemir [2]; Andrzejczak [4]; Gaputienè [8]; Phillips [30]; Sakalas \& Venskus [32]; Simonaitienè [38]; Stewart [39]). The following correlations can be observed in Figure 1.

Evaluation of employees' activity, its relationship with learning, as ability of rapid adjustment to altering circumstances, continuous improvement, psychological factors and inner attitudes and other features characteristic to learning organisation, may highly improve competitive ability of organisations.

\section{Results}

To collect research data we have used questionnaire method. The questionnaire form has been made with reference to scientific works performed, and questionnaires used in those works [5], [8], [9] [22], [41], [44]. In the questionnaire the questions with possible answers were used, when respondent had to choose several answers indicating his situation, questions were made on the principle of Likert scale (used for analysis of attitudes and allowing respondent imparting his opinion, to what degree he agrees or disagrees with particular statement), when respondent has to evaluate in 4 point scale each variant of answer, according to his priorities. Likert scale of 4 point was chosen referring to questionnaire used in doctor's dissertation of Kumpikaitè [22] „Evaluation of personnel learning system”, withdrawing answer "I don't know". In the organisation, which seeks for the efficiency of activity, it is necessary to evaluate not only the features of activity evaluation and learning, but also to reveal the links between them. Therefore in this section we present the comparisons of

Percentage of relationship between evaluation frequency and ways of acquirement of new information

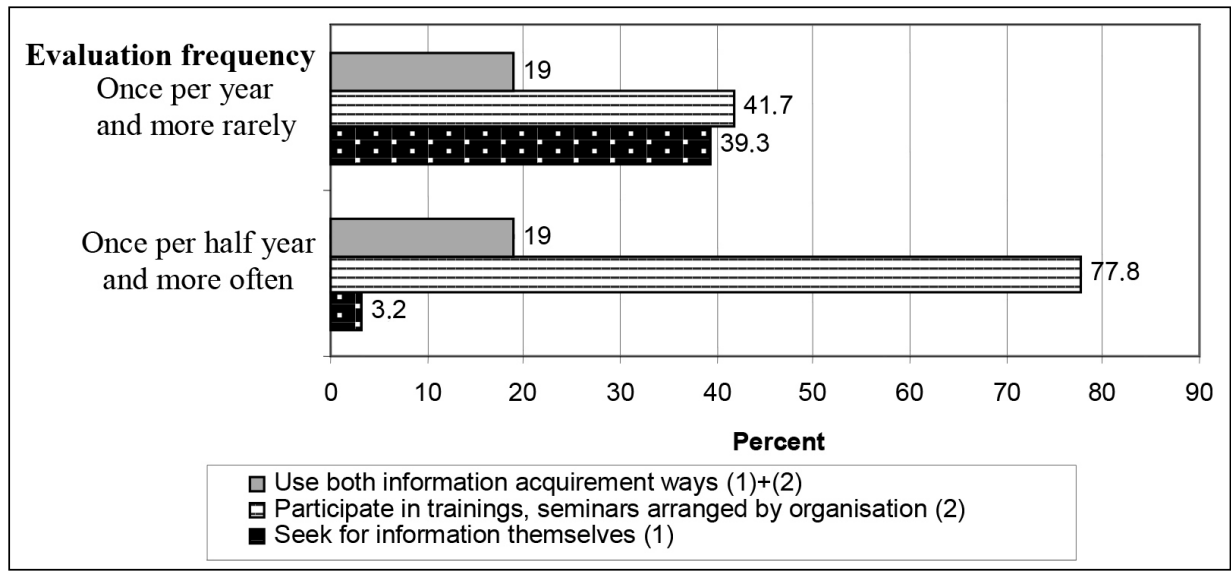

activity evaluation and organisational learning as well as their interdependence.

During the research we explained in what ways respondents acquire new knowledge when activity evaluation is carried out once per year and more rarely, or once a half year and more often (Fig. 2).
Research results show that the more often the employees' activity of leisure \& sports clubs is evaluated, the more rarely respondents seek for information themselves. The fifth of the respondents claimed that they acquire new information by seeking for it themselves and by participating in various trainings. The 
employees evaluated once per year and more rarely according to the ways of new knowledge acquirement groups equally: seek for information themselves - 39.3 percent, participate in the trainings, seminars carried out by organisation -41.7 percent. This means that the frequency of activity evaluation influences the choice of employees in acquirement of new knowledge, since those who are evaluated more often, participate more often in trainings carried out by organisation.

When evaluating relationships presented in theoretical model, we present the link between structural and descriptive methods of activity evaluation with the process of analysis of works performed in organisation. These methods were chosen from all team and individual methods since they are applied in leisure $\&$ sports clubs of Alytus city more often than any others.

In the picture above we may see that carrying out the evaluation using structured methods, mistakes in the organisation usually are analysed when they have subsequence (66.7 percent). This rate indicates that analysis of works performed is carried out quite often and in cases when employees are evaluated according to the importance of separate rates. While the same quantity of respondent employees, who were evaluated using descriptive methods, claimed that they do not analyse the mistakes from the past.
Therefore we are making the conclusion that in organisations researched the analysis of performed works is carried out only sometimes or is not carried out at all. However team (structured) evaluation methods have bigger effect on the fulfilment of work analysis in the organisation.

Hereafter we will present the relationship between mentioned activity evaluation methods and knowledge split ways. The results presented indicate that structured (team) and descriptive (individual) methods of activity evaluation more often determine practical knowledge application in the organisation (66.7 percent) compared to knowledge expression in words, figures and symbols. New knowledge - in words, figures, symbols - to other employees of organisation usually is expressed in evaluation by descriptive method. While using structured methods knowledge expression in both mentioned ways takes part among 33.3 percent of employees of leisure \& sports clubs. This leads to the conclusion that structured and descriptive evaluation methods more positively affect practical knowledge expression in organisation. However team methods are more practiced by the employees of leisure $\&$ sports clubs.

In the leisure \& sports clubs of Alytus city mostly the evaluation function is carried out by immediate manager, but there is lack of knowledge presentation about evaluation

\section{Tab. 1: Influence of employees' evaluation methods on Essential organisation feature}

\begin{tabular}{l|c|c|c}
\multirow{2}{*}{\multicolumn{1}{c|}{ Essential organisation features }} & \multicolumn{2}{c|}{ Methods, M (SN) (score) } & \multirow{2}{*}{ p rate } \\
\cline { 2 - 3 } & Individual & Team & \\
\hline Environment and climate suitable for learning & $3.63(0.74)$ & $3.50(0.58)$ & 0.80 \\
\hline Communication and cooperation of organisation members & $2.88(0.64)$ & $0.25(0.96)$ & 0.40 \\
\hline Reaction to public and environmental needs & $2.88(0.64)$ & $3.75(0.5)$ & 0.04 \\
\hline $\begin{array}{l}\text { Learning, education, knowledge accumulation of } \\
\text { organisation members oriented towards particular goals }\end{array}$ & $3.28(0.74)$ & $3.95(0.31)$ & \multirow{2}{*}{0.04} \\
\hline $\begin{array}{l}\text { Formation of vision, mission, and strategy, which is } \\
\text { organised as learning process }\end{array}$ & $2.88(1.24)$ & $3.25(0.96)$ & 0.60 \\
\hline \begin{tabular}{l|c|c} 
Open organisation expanding its efficiency range \\
Continuously learning organisation
\end{tabular} & $3.10(0.52)$ & $3.95(0.31)$ & 0.01 \\
\hline $\begin{array}{l}\text { Effective processes of knowledge split using up-to-date } \\
\text { information transmission technologies }\end{array}$ & $3.75(0.46)$ & $3.25(0.5)$ & 0.10 \\
\hline Total score: & 26.03 & 25.85 & - \\
\hline
\end{tabular}


criteria to the employees. This negatively affects employees' attitude to evaluation process.

The other very significant interdependence between learning features and activity evaluation methods is presented in Table 18. Respondents have assessed the learning features in the following way: 1 - do not take place, 2 - sometimes take place, 3 - often take place, 4 - always take place, we have made links between individual and team evaluation as well as separate organisation features (all significances obtained by Student test we have verified by Mano-Vitnio test, which suits for comparison of small samples)

In Table 1 we may see, that average score of team evaluation was significantly higher ( $p>0.05$ ), when evaluating reaction to the needs of society and environment, learning, education, knowledge accumulation of organisation members are oriented towards particular goals as well as organisation openness by expanding its activity range.

Individual evaluation is better indicated when analysing the following features of respondents corresponding to the organisation: environment, climate suitable for learning, communication and cooperation of organisation members, effective processes of knowledge split using up-to-date information transmission technologies. And this means, that carrying out team evaluation, respondents note, that mentioned and significantly differing features of learning organisation begin highlighting in the organisation. In turn, the most distinct features influenced by individual evaluation methods are accentuated. This means that team evaluation is more effective when leisure \& sports clubs react to public needs, when learning of organisation members takes place and when organisation activity becomes more effective. While individual evaluation is more effective under the suitable environment and climate for learning, under the processes of communication and cooperation of employees, and constantly exchanging knowledge invoking up-to-date technologies. However we may see that total score of individual and team evaluation is nearly the same. This fact shows that both methods of evaluation, i.e., individual and team, are important for the application, the evaluation itself to be carried out properly and the employee to feel evaluated rightly. The effect of proper evaluation of employee on organisational learning will be only positive.
More than half analysed learning features better highlights when carrying out team evaluation, and three of them (reaction to public and environmental needs; learning, education, knowledge accumulation of organisation members oriented towards particular goals; open organisation expanding its efficiency range) significantly differ from individual evaluation. Structured methods (team level) have more influence when analysing works performed in the organisation and expressing newly acquired knowledge to other organisation employees in practice, than descriptive (individual level) methods.

\section{Conclusions}

Advantages of individual methods: definite number of evaluators, employees are evaluated each individually, exact complex of criteria is determined. However among evaluation methods of this type there are some disadvantages also: evaluation takes much time, data obtained may not be compared, employees are divided into „very good“, "good“ and „bad“, methods are oriented towards several goals. Advantages of team methods: strong and weak sides of employees are accentuated; methods are oriented towards special goals, including also organisational learning aspect. Exactly this reason allows making assumption that team methods could more positively affect organisational learning. However if those team methods are applied inappropriately, disadvantages of team evaluation methods will appear, e.g., in case of incorrect grouping of employees into "the best" and "the worst", we will not have positive effect of employee's evaluation on organisational learning.

In leisure \& sports clubs of Alytus city mostly applied team (structured) evaluation methods more influence analysis of works performed in the organisation than individual (descriptive) methods. When applying used team (structured) and individual (descriptive) evaluation methods, knowledge is applied more practically in work than expressed in words, figures and symbols; the more often the activity of employees is evaluated, the more rarely respondents seek for information themselves. When carrying out team evaluation in the organisation, features of learning organisation are more highlighting, than after the assessment of relationship between features mostly corresponding to the organisation and the most 
acceptable factors motivating learning. Though with different intensity, however all activity evaluation aspects, which have been analysed, influence organisational learning of employees, and in particular team evaluation methods of employees' activity.

Usually in leisure \& sports clubs of Alytus city the activity evaluation function is carried out by immediate manager, but there is lack of knowledge presentation about evaluation criteria to the employees. This negatively affects employees' attitude to evaluation process. Evaluation is mostly performed at the team level with a help of special methods, however individual methods are not also rejected, therefore evaluation method should be chosen by each leisure \& sport club individually. A positive effect of activity evaluation on management and spread of experience and knowledge was determined. Named aspects have some influence on the results of organisation activity, therefore high focus on function of employees' activity evaluation should be taken, and particularly in pursue of competitive advantage increase.

\section{References}

[1] AIVAZ, K.A., VANCEA, D.P.C. A Study of the Black Sea Tourism Companies Efficiency Using Envelope Techniques. Transformations in Business \& Economics. 2009, Vol. 8, Iss. 3, pp. 217-230. ISSN 1648-4460.

[2] AKSU, A., ÖZDEMIR, B. Individual learning and organization culture in learning organizations. Fivestar hotels inAntalya region of Turkey. Managerial Auditing Journal. 2005, Vol. 20 , Iss. 4, pp. 422-441. ISSN 0268-6902. DOI: http://dx.doi.org/10.1108/02686900510592098. [3] ALONDERIENĖ, R., BAKANAUSKIENE், I. Darbuotojų vertinimas komandose. Organizacijy vadyba: sisteminiai tyrimai (Employee evaluation teams. Management of Organizations: Systematic Research). 2004, Vol. 30, pp. 21-33. ISSN 1392-1142.

[4] ANDRZEJCZAK, A. The Changing Role of Learning and Training in Polish Companies. Transformations in Business \& Economics. 2004, Vol. 3, Iss. 2, pp. 124-137. ISSN 16484460.

[5] BAKANAUSKIENĖ, I., BALVOČIŪTĖ, R., BALČIŪNAS, S. Organizaciju mokymosi tyrimas vadybinèje praktikoje. Organizaciju vadyba: sisteminiai tyrimai (Organizational learning in managerial practice. Management of Organizations: Systematic Research). 2006, Vol. 37, pp. 37-46. ISSN 1392-1142.

[6] BALEŽENTIS, A. Inovatyviuju mokymo formy ir metodų taikymo galimybès žmogiškujų išteklių vadyboje. Viešoji politika ir administravimas (In innovative forms of teaching methods and the possibility of human resource management. Public Policy and Administration). 2008, Vol. 26, pp. 97-104. ISSN 1648-2603.

[7] DARŠKUVIENĖ, V., KAUPELYTE், D., PETKEVIČIŪTĖ, N. Vadybinès kompetencijos nustatymo galimybès mokymo procese. Organizaciju vadyba: sisteminiai tyrimai (The possibility of managerial competence in the teaching process. Management of Organizations: Systematic Research). 2008, Vol. 45, pp. 17-28. ISSN 1392-1142.

[8] GAPUTIENĖ, I. Žinių perdavimo sistemos plètojant tarptautinius imonių tinklus. Daktaro disertacija (Knowledge of the transmission system in the development of international business networks. Doctoral dissertation), Kaunas: ISM, 2005.

[9] GIMŽAUSKIENĖ, E. Valdymo apskaitos metodų adaptavimas organizacijos veiklos vertinimo procese. Daktaro disertacija (Management accounting techniques adaptation of the performance measurement process. Doctoral dissertation). Kaunas: Kauno technologijos universitetas, 2004.

[10] GINEVICIUS, R., GINEVICIENE, V. The Compliance of Master's Degree Studies with the Economic Needs of the Country. Technological and Economic Development of Economy. 2009, Vol. 15, Iss. 1, pp. 136-153. ISSN 1392-8619. DOI: 10.3846/1392-8619.2009.15.136-153.

[11] GRUNDEY, D. TQM in university studies: Quality assessment and quality assurance in a Lithuanian University. Transformations in Business \& Economics. 2008, Vol. 7, Iss. 2, pp. 216-235. ISSN 1648-4460.

[12] HOPENIENE, R., RAILIENE, G., KAZLAUSKIENE, E. Potential of Virtual Organizing of Tourism Business System Actors. Inzinerine Ekonomika-Engineering Economics. 2009, Vol. 25, Iss. 3, pp. 75-85. ISSN 1392-2785. [13] YASIN, M.M., ZIMMERER, W.T. The role of benchmarking in achieving continuous service quality. International Journal of Contemporary Hospitality Management. 1995, Vol. 7, Iss. 4, pp. 27-32. ISSN 0959-6119.

[14] JASEVICIUTE-UFARTIENE, L., MEJERYTE-NARKEVICIENE, K., WIDELSKA, U. 
Organizational Development Based on Leader's Self-Development theory and Practice. Transformations in Business \& Economics. 2014, Vol. 13, Iss. 2A, pp. 506-524. ISSN 1648-4460.

[15] JASINSKAS, E. Formation of the European agricultural support model: Reasons, principles and tendencies. Transformations in Business \& Economics. 2008, Vol. 7, Iss. 2, pp. 55-68. ISSN 1648-4460.

[16] JASINSKAS, E., SIMANAVICIENE, Z. Government's support for farmers' knowledge dissemination and its improvement. Inzinerine Ekonomika-Engineering Economics. 2008, Vol. 58, No. 3, pp. 67-72. ISSN 1392-2785.

[17] JEWELL, B.R. Integruotos verslo studijos (Integrated Business Studies). Vilnius: The Baltic Press, 2002.

[18] JUCEVIČIENĖ, P. The alternative trajectories towards the learning organization. Socialiniai mokslai. 2009, Vol. 64, Iss. 2, pp. 2634. ISSN 1392-0758.

[19] KAZLAUSKAITE, R., BUCIUNIENE, I., TURAUSKAS, L., SALCIUVIENE, L. A Comparative Study of Employee Empowerment in Danish and Lithuanian Hotels. Transformations in Business \& Economics. 2009, Vol. 8, Iss. 2, pp. 66-85. ISSN 1648-4460. [20] KERSIENE, K., SAVANEVICIENE, A. The Formation and Management of Organizational Competence Based on Cross-Cultural Perspective. Inzinerine Ekonomika-Engineering Economics. 2009, Vol. 65, Iss. 5, pp. 56-65. ISSN 1392-2785.

[21] KILIJONIENE, A., SIMANAVICIENE, Z., SIMANAVICIUS, A. The Evaluation of Social and Economic Development of the Region. Inzinerine Ekonomika-Engineering Economics. 2010, Vol. 21, Iss. 1, pp. 68-79. ISSN 1392-2785.

[22] KUMPIKAITE், V. Personalo ugdymo sistemos vertinimas. Daktaro disertacija. (Staff development system. Doctoral thesis). Kaunas: Vytauto didžiojo universitetas, 2003.

[23] KONEENIK, M., RUZZIER, M. The customer's perspective on the tourism destination brand: A structural equation modeling study. Transformations in Business \& Economics. 2008, Vol. 7, Iss. 1, pp. 169-184. ISSN 1648-4460.

[24] LIEPE, Z., SAKALAS, A. The threeloop learning model appliance in new product development. Inzinerine EkonomikaEngineering Economics. 2008, Iss. 3, pp. 73-80. ISSN 1392-2785.
[25] MALAKAUSKAITE, A., NAVICKAS, V. Relation between the Level of Clusterization and Tourism Sector Competitiveness. Inzinerine Ekonomika-Engineering Economics. 2010, Vol. 21, Iss. 1, pp. 60-67. ISSN 1392-2785.

[26] MARTINKUS, B., STOSKUS, S., BERZINSKIENE, D. Changes of Employment through the Segmentation of Labour Market in the Baltic States. Inzinerine EkonomikaEngineering Economics. 2009, Iss. 3, pp. 41-48. ISSN 1392-2785.

[27] MELNIKAS, B. Integration Processes in the Baltic Region: the New Form of Regional Transformations in the European Union. Inzinerine Ekonomika-Engineering Economics. 2008, Iss. 5, pp. 54-64. ISSN 1392-2785.

[28] NAVICKAS, V., MALAKAUSKAITE, A. The Possibilities for the Identification and Evaluation of Tourism Sector Competitiveness Factors. Inzinerine Ekonomika-Engineering Economics. 2009, Iss. 1, pp. 37-44. ISSN 1392-2785.

[29] ÖRTENBLAD, A. On differences between organizational learning and learning organization. The Learning Organization. 2001, Vol. 8, Iss. 3, pp. 125-133. ISSN 0969-6474. DOI: http://dx.doi.org/10.1108/09696470110391211. [30] PHILLIPS, B.T. A four-level learning organization benchmark implementation model. The Learning Organization. 2003, Vol. 10, Iss. 2, pp. 98-105. ISSN 0969-6474. DOI: http:// dx.doi.org/10.1108/09696470910462102.

[31] PUNDZIENĖ, A. Profesinio mokymo institucija kaip besimokanti organizacija: problemos ir kaitos gairès. Profesinis rengimas: tyrimai ir realijos (Vocational training institution as a learning organization: Issues and guidelines for change. Vocational Education: Research and Reality). 2002, Iss. 4, pp. 74-83. ISSN 1392-6241. [32] SAKALAS, A., VENSKUS, R. Interaction of Learning Organization and Organizational Structure. Inzinerine Ekonomika-Engineering Economics. 2007, Iss. 3, pp. 65-70. ISSN 13922785.

[33] SARKIUNAITE, I., et al. Link between social capital and quality of life. Transformations in Business \& Economics. 2012, Vol. 11, Iss. 1, pp. 139-153. ISSN 1648-4460.

[34] SARKIUNAITE, I., ROCKE, D. The expatriate experience: the factors of international assignment success. Transformations in Business \& Economics. 2015, Vol. 34, Iss. 1, pp. 20-47. ISSN 1648-4460.

[35] SAVRINA, B., GRUNDEY, D., BERZINA, K. Cooperation - The form of sustainable 
tourism industry in Latvia. Technological and Economic Development of Economy. 2008, Vol. 14, Iss. 2, pp. 151-161. ISSN 1392-8619. DOI: 10.3846/1392-8619.2008.14.151-161.

[36] SENGE, P. Besimokanti mokykla (The Learning School). Vilnius, 2008.

[37] SERAFINAS, D., RUŽEVIČIUS, J. Aukštujų mokyklų veiklos tobulinimo pokyčių kontekste įžvalgos. Ekonomika ir vadyba (High school improvement context of changes in insight. Economics and Management). 2009, Iss. 14, pp. 1091-1099. ISSN 1822-6515.

[38] SIMONAITIENE், B. Mokyklos besimokančios organizacijos vystymas. Mokslo studija (School - a learning organization development. Science study). Kaunas: Technologija, 2007.

[39] STEWART, D. Reinterpreting the learning organisation. The Learning Organization. 2001, Vol. 8, Iss. 4, pp. 141-152. ISSN 0969-6474. DOI: http://dx.doi.org/10.1108/EUM0000000005607. [40] SLIZYTE, A., BAKANAUSKIENE, I. Designing performance measurement system in organization. Organizaciju vadyba: sisteminiai tyrimai. 2007, No. 43, pp. 135-148. ISSN 1392-1142.

[41] TUBUTIENE், V., MORKŪNAITÉ, S. Organizacinio mokymosi modeliai besimokančioje organizacijoje. Ekonomika ir vadyba: aktualijos ir perspektyvos (Organizational learning models in a learning organization. Economics and Management: Current Issues and Perspectives). 2008, Vol. 1, Iss. 10, pp. 200-211. ISSN 1648-9098.

[42] URBAN, W. Service Quality Gaps and Their Role in Service Enterprises Development. Technological and Economic Development of Economy. 2009, Vol. 15, Iss. 4, pp. 631645. ISSN 1392-8619. DOI: 10.3846/13928619.2009.15.631-645.
[43] ZAFIROPOULOS, C., VRANA, V. Service quality assessment in a Greek Higher Education Institute. Journal of Business Economics and Management. 2008, Vol. 9, Iss. 1, pp. 33-45. ISSN 1611-1699. DOI:10.3846/16111699.2008.9.33-45.

[44] ZUZEVIČIŪTĖ, V., TERESEVIČIUS, T. Besimokančios organizacijos kūrimo prielaidos. Organizaciju vadyba: sisteminiai tyrimai (Learning organization development assumptions. Management of Organizations: Systematic Research). 2008, No. 45, pp. 115126. ISSN 1392-1142.

prof. Edmundas Jasinskas, Ph.D. Lithuanian Sports University Faculty of Sport Education Department of Sport Management Economics and Sociology edmundas.jasinskas@Isu.It

prof. Dalia Štreimikienè, Ph.D. Lithuanian Sports University Institute of Sport Science and Innovations dalia.streimikiene@Isu.It

assoc. prof. Biruta Švagždienè, Ph.D. Lithuanian Sports University Faculty of Sport Education Department of Sport Management Economics and Sociology biruta.svagzdiene@Isu.It

lecturer Artūras Simanavičius, Ph.D. Lithuanian Sports University Faculty of Sport Education Department of Sport Management Economics and Sociology arturas.simanavicius@Isu.It 


\section{INFLUENCE OF EMPLOYEES EVALUATION ON ORGANISATIONAL LEARNING AT LEISURE \& SPORTS CLUBS}

\section{Edmundas Jasinskas, Dalia Štreimikienè, Biruta Švagždienè, Artūras Simanavičius}

Every organisation including leisure \& sports clubs reach for their goals. People working at the organisation have to ensure the goals set were reached, and in order to control this process properly the evaluation of employees' activity is necessary.

The importance of employees' evaluation function for welfare of organisation is evident, however it would be much more important, if together with evaluation of employees, the purposeful learning of both individual employees and entire organisation would also be increased. Evaluation of employees is significant for the results of organisation, for evaluation of knowledge available and for learning from the experience, undoubtedly, the motivation of learning is related to incentive of employees' evaluation too. Thus it may be stated, that evaluation of employees is an important incentive instrument for learning of employee as well as organisation. This instrument must be constantly improved since only in such a case the evaluation of employees' activity will be useful for the employee and organisation itself in enhancement of different level learning and competitive ability.

It is assumed in the article that team methods of employees' evaluation at leisure \& sports clubs of Alytus city more affect the characteristics of learning organisation features than individual methods of employees' evaluation. Such tendency indicates that applying only individual evaluation methods the organisation does not initiate the employees to share their knowledge with other organisation members, thereby decreases common learning of whole organisation.

Key Words: Employees' evaluation, organisational learning, leisure \& sports clubs.

JEL Classification: M12, M53.

DOI: 10.15240/tul/001/2015-3-004 